\title{
EFFECT OF INITIAL STRUCTURE AND COLD DEFORMATION ON THE STRESS - ELONGATION CURVE OF DUPLEX STAINLESS STEEL $(\alpha+\gamma)$ IN A STATIC TENSILE TESTING AT $850^{\circ} \mathrm{C}$
}

\begin{abstract}
The results presented in the article concern the effect of structure and cold deformation on the behaviour of a highalloy duplex stainless steel $(\alpha+\gamma)$, grade X2CrNiMoN22-5-3, in tensile tests at $850^{\circ} \mathrm{C}$ at a rate $v_{r}=15 \cdot 10^{-3} \mathrm{~mm} / \mathrm{s}$. Tests were carried out for a sheet after supersaturation from 1250 and $1350^{\circ} \mathrm{C}$ and subsequent cold rolling with the values of $\varepsilon_{h}$ deformation within the range of 0.5-0.9. It was shown that the material undergoes superplastic flow, which is associated with the $\alpha \rightarrow \gamma+\sigma$ transformation occurring at the tensile testing temperature. It was shown that the superplasticity effect depends on the initial structure and is greater for the material supersaturated from $1350^{\circ} \mathrm{C}$ as compared to $1250^{\circ} \mathrm{C}$. This effect also increases with the increase of the cold deformation value of the sheet. It was proven that increasing cold deformation causes, after tensile testing at $850^{\circ} \mathrm{C}$, an increase in the area fraction of the $\sigma$ phase inhibiting the austenite grain growth in the steel structure.
\end{abstract}

Keywords: duplex stainless steel $(\alpha+\gamma)$, high temperature tensile test, stress-elongation curves, structure

\section{WPEYW STRUKTURY WYJŚCIOWEJ I ODKSZTAŁCENIA NA ZIMNO NA POSTAĆ KRZYWEJ NAPRĘ̇̇ENIE - WYDEUŻENIE STALI TYPU DUPLEX $(\alpha+\gamma)$ W STATYCZNEJ PRÓBIE ROZCIĄGANIA W TEMPERATURZE $850^{\circ} \mathrm{C}$}

\begin{abstract}
Wyniki przedstawione $w$ artykule dotyczq wptywu struktury $i$ odksztatcenia na zimno na zachowanie się wysokostopowej stali typu duplex $(\alpha+\gamma)$, gatunek X2CrNiMoN22-5-3, w próbach rozciagania $w$ temperaturze $850^{\circ} \mathrm{C} z$ prędkościa $v_{r}=15 \cdot 10^{-3} \mathrm{~mm} / \mathrm{s}$. Badaniom poddano blachę po przesycaniu z temperatury $1250 \mathrm{i} 1350^{\circ} \mathrm{C} i$ następnym walcowaniu na zimno $z$ wartościami odkształcenia $\varepsilon_{h} w$ zakresie $0,5 \div 0,9$. Wykazano, że materiat ulega nadplastycznemu plynięciu, co jest zwiazane $z$ przemiana $\alpha \rightarrow \gamma+\sigma$ zachodzaca $w$ temperaturze rozciagania. Wykazano, że efekt nadplastyczności zależy od struktury wyjściowej i jest większy w przypadku materiału przesyconego $z 1350^{\circ} \mathrm{C} w$ porównaniu do $1250^{\circ} \mathrm{C}$. Efekt ten zwiększa się również ze wrrostem wartości odksztatcenia na zimno blachy. Udowodniono, że zwięhszanie odkształcenia na zimno powoduje, po rozciaganiu $w$ temperaturze $850^{\circ} \mathrm{C}$, wzrost udziału fazy $\sigma$ hamujacej rozrost ziarn austenitu $w$ strukturze stali.
\end{abstract}

Stowa kluczowe: stal odporna na korozje typu duplex $(\alpha+\gamma)$, wysokotemperaturowa próba rozciagania, krzywe naprężenie-wydłużenie, struktura

\section{INTRODUCTION}

Duplex stainless steels $(\alpha+\gamma)$ are widely and continuously more often used in various industries, including the chemical, petrochemical and energy industry [1,2]. They are used to manufacture products such as tanks, heat exchangers, pipelines, pumps or even bridge construction components [3, 4]. Ferritic-austenitic steels are an alternative to single-phase steels with austenitic structure not only due to their properties, but also due to their lower manufacturing costs related to lower nickel content $[5,6]$. These materials are characterised by very good corrosion resistance combined with high strength. However, they show much lower limiting deformability during hot forming compared to high-alloy steels with a single-phase ferritic and austenitic structure, which limits their applicability [7-9].
The problems in forming them result from the different properties of both phases that make up their structure. There are possibilities to increase the deformability of duplex stainless steel $(\alpha+\gamma)$ by using complex mechanisms of plastic deformation, leading to obtaining the effect of superplasticity $[10,11]$. The effect is most often determined by: heat treatment, cold rolling deformation (usually more than $50 \%$ of the draft) and tensile test at both elevated temperature and very low rates. Parameters of heat treatment as well as deformation processes ensuring obtaining a fine-grained structure are often protected by patents [12].

This paper analyses the influence of the initial structure and cold deformation on the obtained values of elongation in static tensile tests at $850^{\circ} \mathrm{C}$ and the structure after these tests. 


\section{TESTING METHODOLOGY}

The test material was a sheet of high-alloy ferriticaustenitic steel X2CrNiMoN22-5-3 (Fig. 1) supersaturated from $T=1250^{\circ} \mathrm{C}$ and $T=1350^{\circ} \mathrm{C}$ with the chemical composition shown in Table 1.

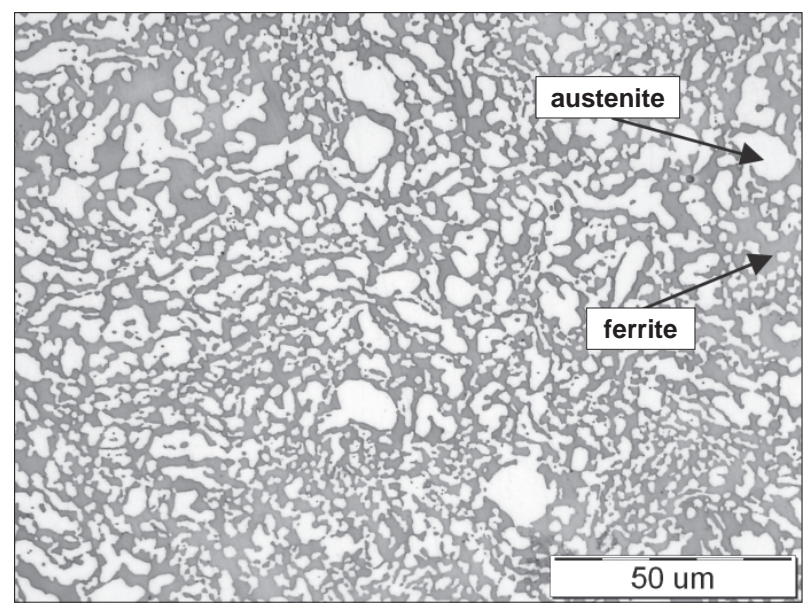

Fig. 1. Structure of the investigated ferritic-austenitic steel as delivered. LOM

Rys. 1. Struktura badanej stali ferrytyczno-austenitycznej w stanie dostawy. LOM

The sheet with the initial height $h_{0}=3 \mathrm{~mm}$ was cold rolled, obtaining the following values of the total relative draft $\varepsilon_{h}=0.5 ; 0.7 ; 0.9$. Then, flat samples for tensile tests at elevated temperature were made with an initial length of $3 \mathrm{~mm}$ measuring base. The samples were heated at a rate of about $42^{\circ} \mathrm{C} / \mathrm{min}$. to a tensile temperature, i.e. $T=850^{\circ} \mathrm{C}$, after which they were annealed at this temperature for 5 minutes. Tensile tests were carried out at a rate $v_{r}=15 \cdot 10^{-3} \mathrm{~mm} / \mathrm{s}$ in a $0.005 \mathrm{~Pa}$ vacuum. The obtained elongation was marked as $A_{3 \mathrm{~mm}}$. After the preset elongation, the samples were cooled with compressed air. The structure was examined with the use of a light microscope and transmission electron microscope. The quantitative analysis of the structure was carried out at a distance of $2 \mathrm{~mm}$ from the fracture using the original METILO software [13]. The following were determined:

- area fraction of individual phases $A_{\mathrm{A}}$ [\%]

- the average area of a plane section of a grain (precipitate) $\bar{A}\left[\mathrm{~m}^{2}\right]$

- grain plane section variability coefficient v $(\bar{A})[\%]$.

\section{TEST RESULTS}

The structure of the steel after supersaturation from $T=1250^{\circ} \mathrm{C}$ is composed of $70 \pm 0.5 \%$ ferrite and $30 \pm 0.5 \%$ austenite (Fig. 2a). Annealing at $T=1350^{\circ} \mathrm{C}$ results in a ferritic phase with a small amount (i.e. $2.8 \%$ ) of austenite in the steel structure (Fig. 2b).
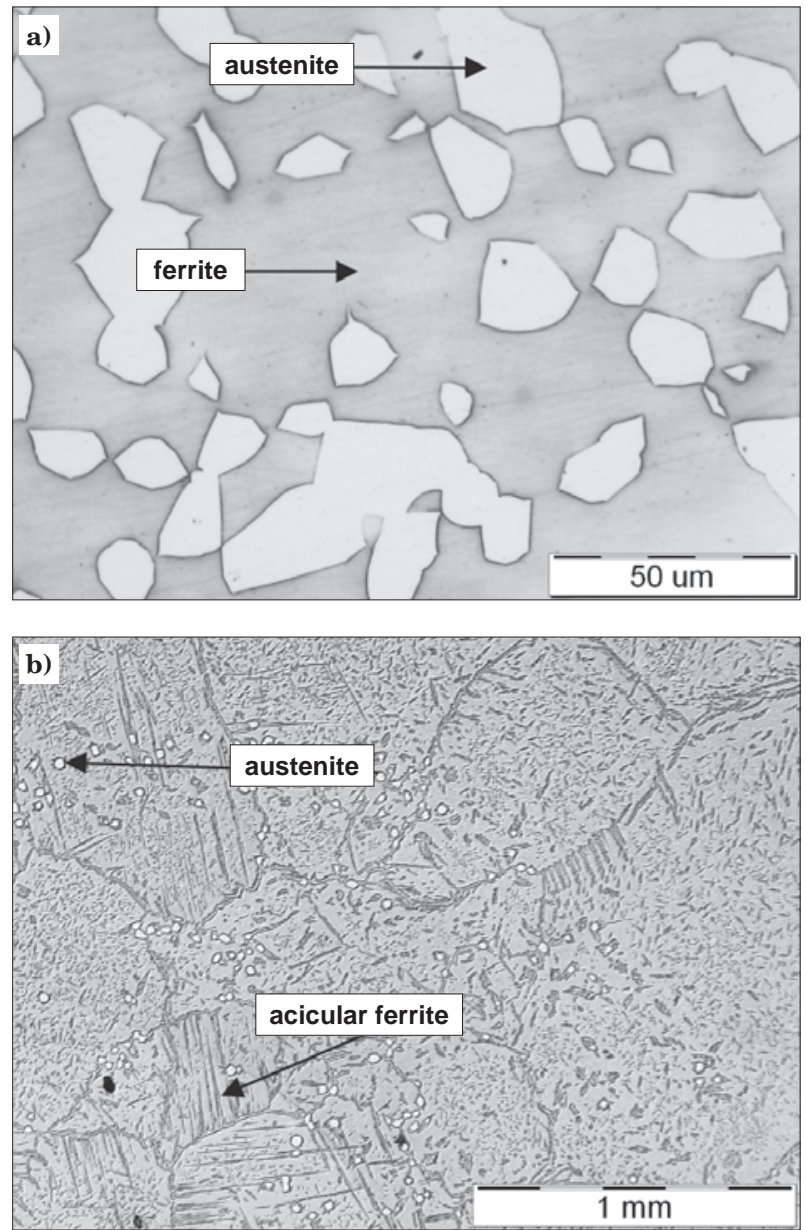

Fig. 2. Structure of the X2CrNiMoN22-5-3 steel after supersaturation from: a) $1250^{\circ} \mathrm{C}$, b) $1350^{\circ} \mathrm{C}$, with an annealing time of $60 \mathrm{~min}$. and cooling in water. LOM

Rys. 2. Struktura stali X2CrNiMoN22-5-3 po przesycaniu z temperatury: a) $1250^{\circ} \mathrm{C}$, b) $1350^{\circ} \mathrm{C}, \mathrm{z}$ czasem wygrzewania 60 min. i chłodzeniem w wodzie. LOM

Tensile tests were carried out both on the supersaturated material without deformation and after cold deformation.

The effect of the cold preset total relative draft on the form of stress curves in the $\mathrm{F}$ force $-A_{3 \mathrm{~mm}}$ elongation system is shown in Figures 3 and 4.

In the tested steel, during tensile test at $850^{\circ} \mathrm{C}$ at the rate $v_{r}=15 \cdot 10^{-3} \mathrm{~mm} / \mathrm{s}$, there is a superplastic flow effect, which is evidenced by the obtained values of elongation to fracture $A_{3 \mathrm{~mm}}$.

The increase in cold deformation for samples supersaturated from $1250^{\circ} \mathrm{C}$ and $1350^{\circ} \mathrm{C}$ causes an increase in elongation to fracture $A_{3 \mathrm{~mm}}$ (Fig. 3-5). The largest elongation $A_{3 \mathrm{~mm}}$ was obtained at the largest preset relative drafts $\varepsilon_{h}=0.9$ and it amounted to: $A_{3 \mathrm{~mm}}=$ $829 \%$ for the steel supersaturated from $T=1250^{\circ} \mathrm{C}$ and $A_{3 \mathrm{~mm}}=1051 \%$ for the steel supersaturated from $T=1350^{\circ} \mathrm{C}$.

Table 1. Chemical composition of steel X2CrNiMoN22-5-3 (wt \%)

Tabela 1. Skład chemiczny stali X2CrNiMoN22-5-3 (w \% mas.)

\begin{tabular}{|c|c|c|c|c|c|c|c|c|c|}
\hline $\mathbf{C}$ & $\mathbf{S i}$ & $\mathbf{M n}$ & $\mathbf{N i}$ & $\mathbf{C r}$ & $\mathbf{M o}$ & $\mathbf{N}$ & $\mathbf{S}$ & $\mathbf{F}$ & $\mathbf{N b}$ \\
\hline 0.017 & 0.30 & 1.57 & 5.45 & 22.82 & 3.12 & 0.169 & 0.0009 & 0.019 & 0.004 \\
\hline
\end{tabular}




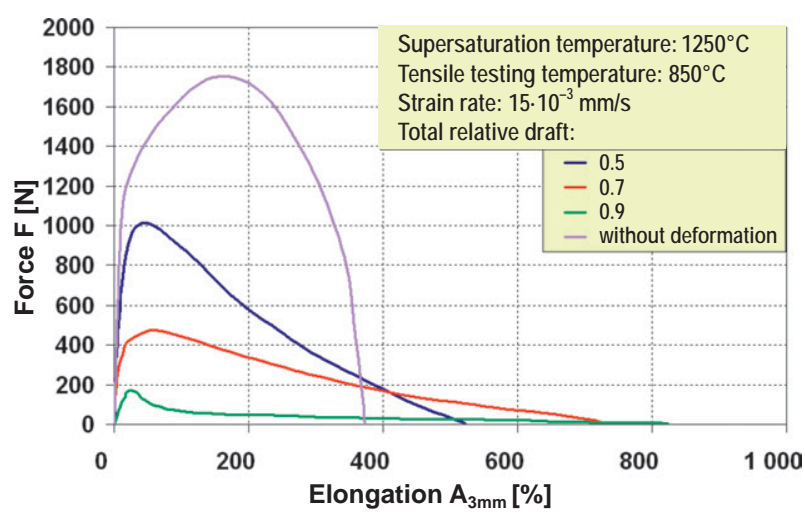

Fig. 3. Effect of cold preset relative draft $\varepsilon_{h}$ on the form of the force $-A_{3 \mathrm{~mm}}$ elongation curves for the steel supersaturated from $T=1250^{\circ} \mathrm{C}$

Rys. 3. Wpływ gniotu względnego $\varepsilon_{h}$ zadanego na zimno na postać krzywych siła - wydłużenie $A_{3 \mathrm{~mm}}$ dla stali przesyconej z $T=1250^{\circ} \mathrm{C}$

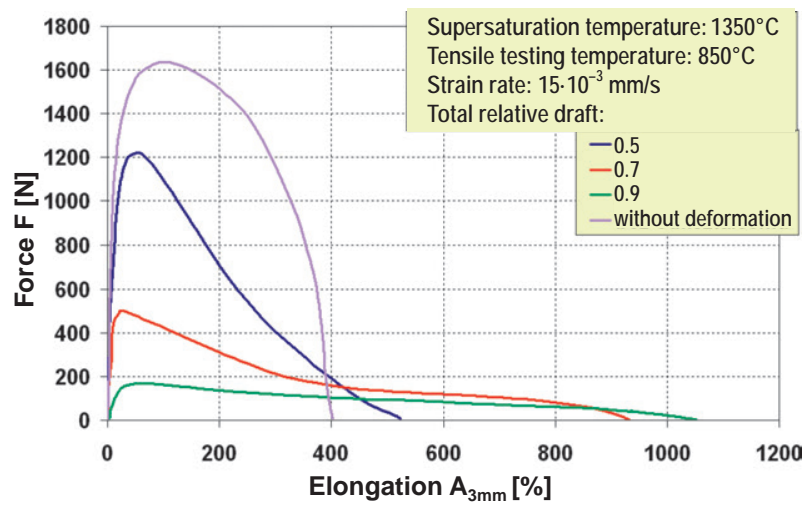

Fig. 4. Effect of cold preset relative draft $\varepsilon_{h}$ on the form of the force $-A_{3 \mathrm{~mm}}$ elongation curves for the steel supersaturated from $T=1350^{\circ} \mathrm{C}$

Rys. 4. Wpływ gniotu względnego $\varepsilon_{h}$ zadanego na zimno na postać krzywych siła - wydłużenie $A_{3 \mathrm{~mm}}$ dla stali przesyconej z $T=1350^{\circ} \mathrm{C}$

Steel supersaturated from $T=1350^{\circ} \mathrm{C}$ and cold rolled to the same value of relative draft as the steel supersaturated from $T=1250^{\circ} \mathrm{C}$ deforms under the same tensile parameters to greater $A_{3 \mathrm{~mm}}$ elongations (Fig. 5).

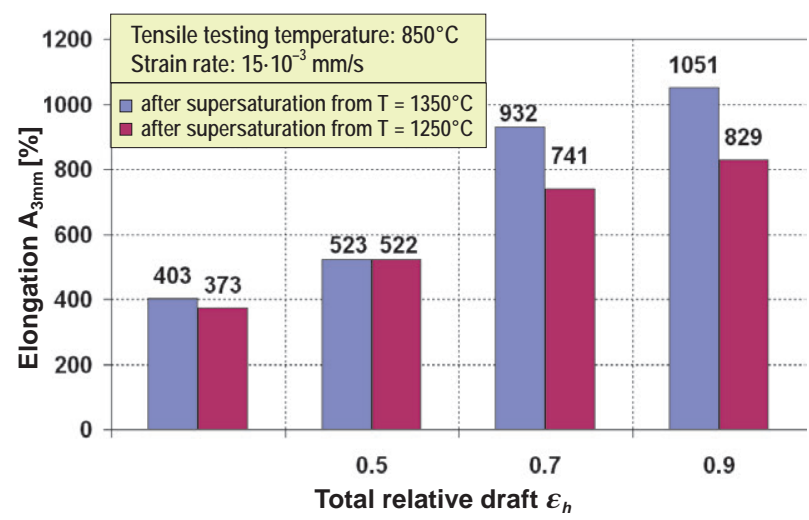

Fig. 5. Effect of cold preset relative draft $\varepsilon_{h}$ on the value of elongation to fracture $A_{3 \mathrm{~mm}}$ of the steel supersaturated from $T=1250^{\circ} \mathrm{C}$ and $T=1350^{\circ} \mathrm{C}$

Rys. 5. Wpływ całkowitego gniotu względnego $\varepsilon_{h}$ na zimno na wartość wydłużenia do rozerwania $A_{3 \mathrm{~mm}}$ stali przesyconej z $T=1250^{\circ} \mathrm{C}$ i $T=1350^{\circ} \mathrm{C}$
In steel after heating to the tensile testing temperature, i.e. $T=850^{\circ} \mathrm{C}$, ferrite is transformed $(1)[14,15]$ :

$$
\alpha \rightarrow \gamma+\sigma
$$

As a result, there is coarse-grained austenite formed during the supersaturation and fine-grained austenite with $\sigma$ phase precipitates formed as a result of ferrite transformation in the structure of steel supersaturated from $T=1250^{\circ} \mathrm{C}$ and tensile tested at $T=850^{\circ} \mathrm{C}$ (Fig. 6a). The structure of the material supersaturated from $T=1350^{\circ} \mathrm{C}$ after tensile test is composed of finegrained austenite and an evenly distributed $\sigma$ phase (Fig. 6b). The presence of $\sigma$ phase in the structure of the samples after tensile testing at $T=850^{\circ} \mathrm{C}$ was confirmed using transmission electron microscopy (Fig. 7).
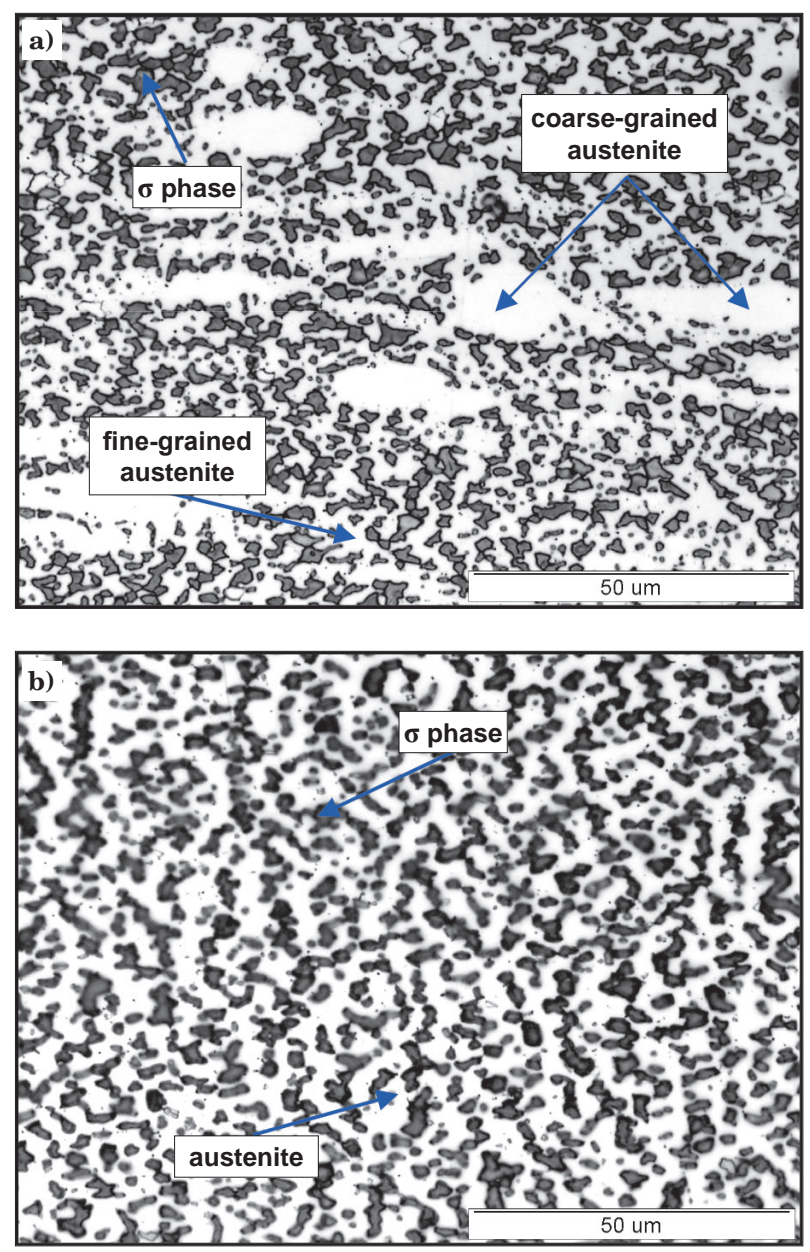

Fig. 6. Structure of cold rolled steel with $\varepsilon_{h}=0.7$ and then subjected to tensile testing at $T=850^{\circ} \mathrm{C}$ at a rate $v_{r}=15 \cdot 10^{-3}$ $\mathrm{mm} / \mathrm{s}$ : a) supersaturated from $T=1250^{\circ} \mathrm{C}$, b) supersaturated from $T=1350^{\circ} \mathrm{C}$

Rys. 6. Struktura stali odkształconej na zimno z $\varepsilon_{h}=0,7$ i następnie rozciąganej $\mathrm{w} T=850^{\circ} \mathrm{C}$ zrędkością $v_{r}=$ $15 \cdot 10^{-3} \mathrm{~mm} / \mathrm{s}$ : a) przesyconej z $T=1250^{\circ} \mathrm{C}$, b) przesyconej $\mathrm{z} T=\mathrm{1350}^{\circ} \mathrm{C}$

The effect of tensile testing at $T=850^{\circ} \mathrm{C}$ at a rate $v_{r}=15 \cdot 10^{-3} \mathrm{~mm} / \mathrm{s}$ of the steel supersaturated from $T=1250^{\circ} \mathrm{C}$ and $T=1350^{\circ} \mathrm{C}$ and cold rolled $\varepsilon_{h}=0.5$; $0.7 ; 0.9$ on changes in the area fraction of the $\sigma$ phase, the average area of the plane section of $\sigma$ phase precipitates and its inhomogeneities are shown in Figures 8-10. 

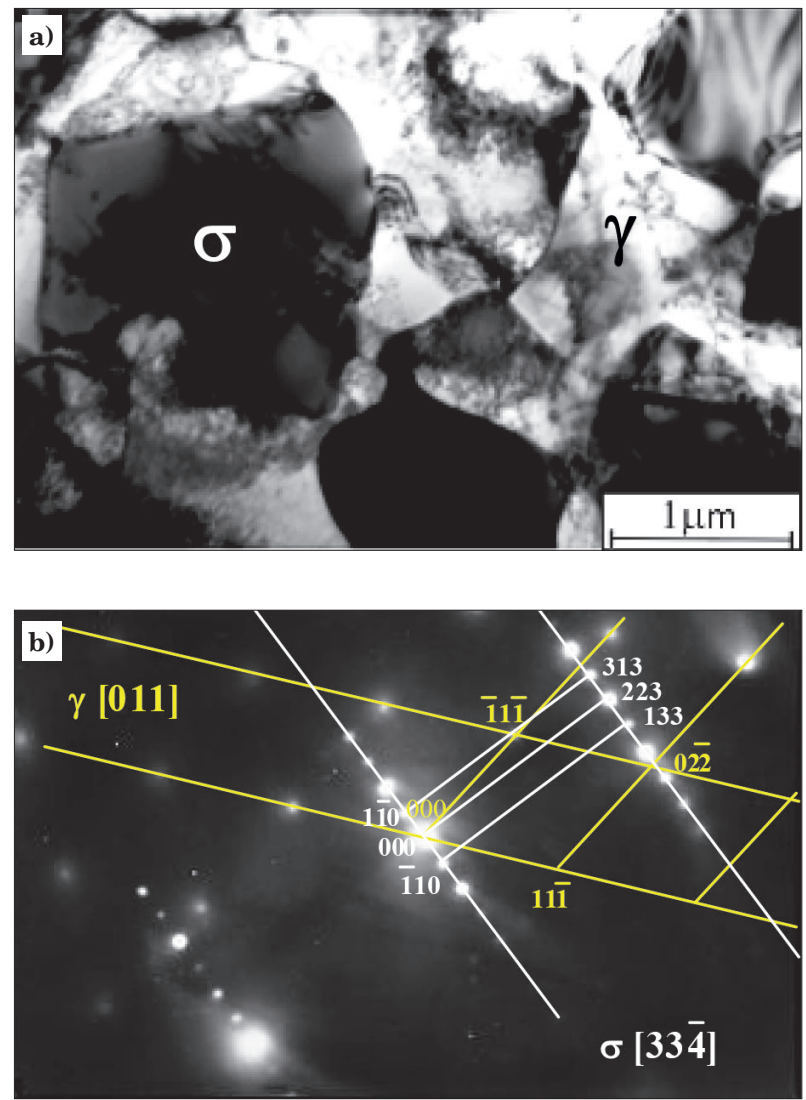

Fig. 7. Sub-structure of steel supersaturated from $T=$ $1350^{\circ} \mathrm{C}$, cold-rolled with $\varepsilon_{h}=0.7$ and then subjected to tensile testing at $T=850^{\circ} \mathrm{C}$ at a rate $v_{r}=15 \cdot 10^{-3} \mathrm{~mm} / \mathrm{s}$ (a) and diffraction resolution from the centre of Fig. a (b)

Rys. 7. Substruktura stali przesyconej $\mathrm{z} T=1350^{\circ} \mathrm{C}$, odkształconej na zimno z $\varepsilon_{h}=0,7$ i następnie rozciąganej w $T=850^{\circ} \mathrm{C}$ z prędkością $v_{r}=15 \cdot 10^{-3} \mathrm{~mm} / \mathrm{s}$ (a) oraz rozwiązanie dyfrakcji ze środka rys. a (b)

The lowest area fraction of $\sigma$ phase was obtained for both supersaturated states after tensile testing without prior cold deformation. It was $A_{\mathrm{A}}=9.5 \pm 0.4 \%$ and $A_{\mathrm{A}}=10.3 \pm 0.4 \%$ respectively (Fig. 8). An increase in the strain value within the $\varepsilon_{h}=0.5-0.9$ range increases the area fraction of $\sigma$ phase, both for the steel supersaturated from $T=1250^{\circ} \mathrm{C}$ and for the steel supersaturated from $T=1350^{\circ} \mathrm{C}$. At identical values of

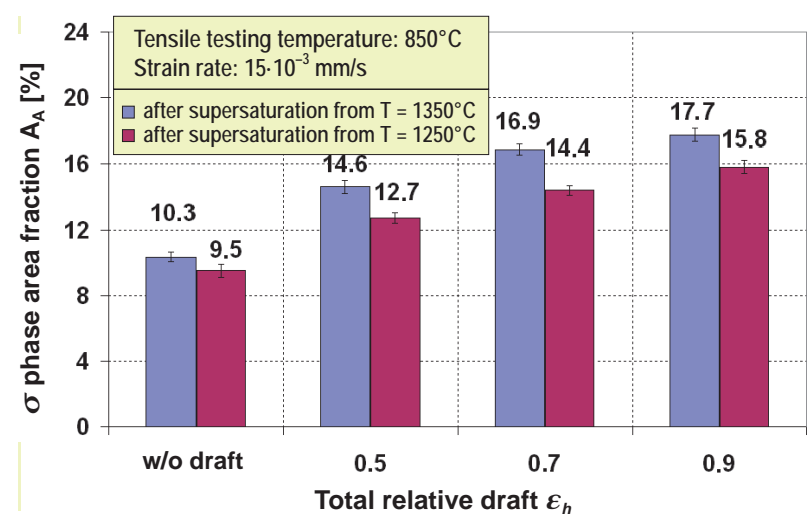

Fig. 8. Effect of the cold preset total relative draft $\varepsilon_{h}$ on changes in the $\sigma$ phase area fraction

Rys. 8. Wpływ całkowitego gniotu względnego zadanego na zimno $\varepsilon_{h}$ na zmiany udziału powierzchniowego fazy $\sigma$

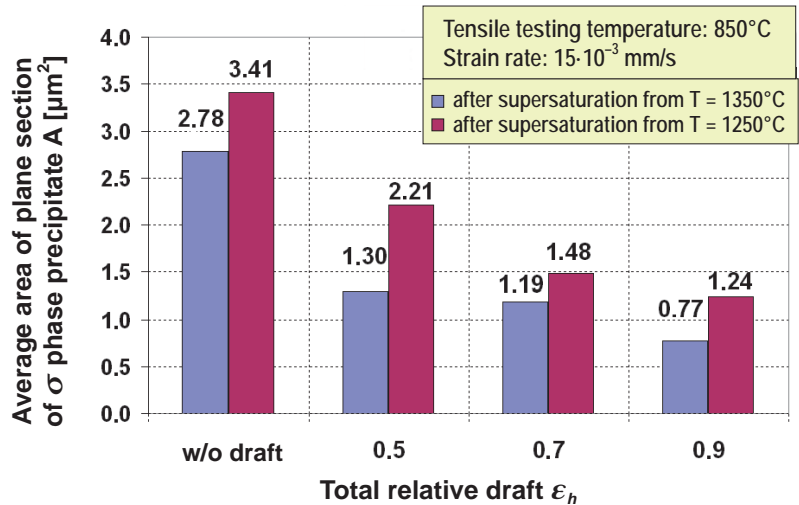

Fig. 9. Effect of the cold preset total relative draft $\varepsilon_{h}$ on the average area of plane section of $\sigma$ phase precipitate

Rys. 9. Wpływ całkowitego gniotu względnego zadanego na zimno $\varepsilon_{h}$ na średnią powierzchnię płaskiego przekroju wydzielenia fazy $\sigma$

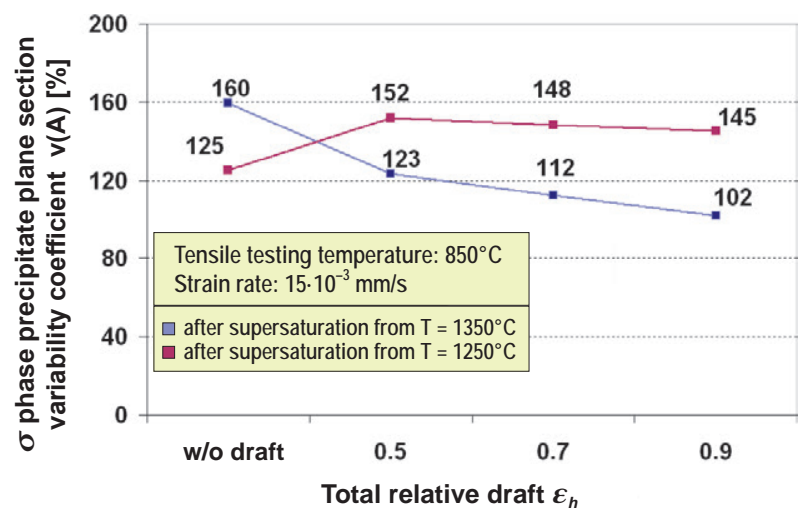

Fig. 10. Effect of the cold preset total relative draft $\varepsilon_{h}$ on the $\sigma$ phase precipitate

Rys. 10. Wpływ całkowitego gniotu względnego zadanego na zimno $\varepsilon_{h}$ na niejednorodność wydzielenia fazy $\sigma$

deformation, the area fraction of $\sigma$ phase is greater for the steel supersaturated from $T=1350^{\circ} \mathrm{C}$. This is also due to differences in the initial steel structure before tensile testing. The steel after supersaturation from $T=1350^{\circ} \mathrm{C}$ was single-phase $(\alpha)$, whereas after supersaturation from $T=1250^{\circ} \mathrm{C}$ it was two-phase $(\alpha+\gamma)$.

The average area of a plane section of $\sigma$ phase precipitates after tensile testing at $T=850^{\circ} \mathrm{C}$ at a rate $v_{r}=15 \cdot 10^{-3} \mathrm{~mm} / \mathrm{s}$ of the steel supersaturated from $T=1250^{\circ} \mathrm{C}$ is $\bar{A}=3.41 \mathrm{~mm}^{2}$, and is higher than the value obtained for the steel after supersaturation from $1350^{\circ} \mathrm{C}$, which is $\bar{A}=2.78 \mathrm{~mm}^{2}$ (Fig. 9). An increase in the strain value within the $\varepsilon_{h}=0.5-0.9$ range leads to a reduction in the size of the $\sigma$ phase precipitates, and the size of precipitates with identical strain values is greater for the steel after supersaturation from $T=1250^{\circ} \mathrm{C}$ than from $T=1350^{\circ} \mathrm{C}$ (Fig. 9).

The inhomogeneity of precipitate sizes of phase of the steel after supersaturation from $T=1350^{\circ} \mathrm{C}$ is higher compared to the steel supersaturated from $T=1250^{\circ} \mathrm{C}$ (Fig. 10). Cold deformation in the range of $\varepsilon_{h}=0.5-0.9$ increases this inhomogeneity after fracture with the same deformation parameters for steel after supersaturation from $T=1250^{\circ} \mathrm{C}$ (Fig. 10). The increase in deformation leads to the homogenisation of the size of precipitates of $\sigma$ phase, especially after supersaturation from $T=1350^{\circ} \mathrm{C}$. 


\section{CONCLUSIONS}

Tensile tests at $850^{\circ} \mathrm{C}$ carried out for the steel supersaturated from $T=1250^{\circ} \mathrm{C}$ with a ferritic-austenitic structure and from $T=1350^{\circ} \mathrm{C}$ with a ferritic structure, both without pre-deformation and after cold rolling, showed the effect of initial structure and cold deformation on the obtained values of elongation to fracture $A_{3 \mathrm{~mm}}$.

The use of cold rolling before tensile testing of the steel at elevated temperature results in elongation to fracture $A_{3 \mathrm{~mm}}$ several hundred percent higher as compared to the steel without deformation. The increase of the cold deformation value in the $\varepsilon_{h}=0.5-0.9$ range causes the increase of the subsequent elongation to fracture $A_{3 \mathrm{~mm}}$. With the increase in cold deformation $\varepsilon_{h}$, the number of potential nucleation sites of new aus- tenite grains and $\sigma$ phase precipitates increases. The higher the preset cold deformation, the finer $\sigma$ phase precipitates, and the greater their area fraction, after tensile tests at $T=850^{\circ} \mathrm{C}$. With identical tensile parameters, higher elongation to fracture $A_{3 \mathrm{~mm}}$ values were achieved for the steel with an initial single-phase structure as compared to the steel with a two-phase structure. The uniformity of $\sigma$ phase distribution inhibiting austenite grain growth also affects the obtained elongation values. The distribution of $\sigma$ phase precipitates in the case of steel supersaturated from $T=1250^{\circ} \mathrm{C}$ is uneven compared to the steel supersaturated from $T=1250^{\circ} \mathrm{C}$, and results from the presence, in addition to fine-grained austenite formed as a result of ferrite transformation, of coarse-grained austenite formed after supersaturation in the steel structure.

\section{REFERENCES}

[1] Y.H. Park, Z.H. Lee. The effect of nitrogen and heat treatment on the microstructure and tensile properties of 25 Cr-7Ni-1.5Mo-3W-xN duplex stainless steel castings. Materials Science and Engineering A. 2001, 297, p. 78-84.

[2] K.M. Lee, H.S. Cho, D.C. Choi. Effect of isothermal treatment of SAF 2205 duplex stainless steel on migration of $\delta / \gamma$ interface boundary and growth of austenite. Journal of Alloy and Compounds. 1999, 285, p. 156-161.

[3] T. Siegmund, E. Werner, F.D. Fischer. On the thermomechanical deformation behavior of duplex-type materials. Journal of Mechanics and Physics of Solids 1995, 43, p. 495-532.

[4] J. Charles. Duplex stainless steels: from the theory to the practice. Stainless Steel 93, Firenze, 1993, (3) p. 29.

[5] J. Łabanowski. Dwufazowe stale odporne na korozję. Przeglad Mechaniczny. 1995, 23-24.

[6] A. Itman Filho, J.M.D.A. Rollo, R.V. Silva, G. Martinez. Alternative process to manufacture austenitic-ferritic stainless steel wires. Materials Letters. 2005, 59 (10), p. 11921194.

[7] G. Niewielski. Zmiany struktury i właściwości stali austenitycznej odkształcanej na gorąco. Zeszyty Naukowe. Hutnictwo, Politechnika Śląska, 2000, issue 58.

[8] K. Radwański. Analiza struktury i właściwości wysokostopowej stali typu duplex $(\alpha+\gamma)$ odksztatcanej na goraco. Doc- toral Dissertation, Silesian University of Technology, Faculty of Materials Engineering and Metallurgy, Katowice 2005, unpublished.

[9] G. Niewielski, D. Kuc, K. Radwański. Structure and mechanical properties of hot deformed high-alloy ferritic steel. Inżynieria Materiałowa 2004, 25 (3), p. 400-403.

[10] H. Miyamoto, T. Mimaki, S. Hashimoto. Superplastic deformation of micro-specimens of duplex stainless steel. Materials Science and Engineering A 319-321. 2001, p. 779-783.

[11] K. Radwański, K. Rodak, G. Niewielski. Zmiany struktury podczas odkształcania nadplastycznego stali typu duplex $(\alpha+\gamma)$. Inżynieria Materiałowa 2007 (5), p. 846-849.

[12] J. Jiménez, G. Frommeyer, M. Carsí, O.A. Ruano. Superplastic properties of a $\delta / \gamma$ stainless steel. Materials Science and Engineering A. 2001, 307 (1), p. 134-142

[13] J. Szala. Program komputerowy do analizy obrazu „Metalografia Ilościowa”. Katowice, 1997.

[14] A. Gironès, L. Llanes, M. Anglada, A. Mateo. Dynamic strain ageing effects on superduplex stainless steels at intermediate temperatures. Materials Science and Engineering A. 2004 367 (1-2), p. 322-328.

[15] J.J. Moverare, M. Odén. Deformation behaviour of a prestrained duplex stainless steel. Materials Science and Engineering A. 2002, 337 (1-2), p. 25-38. 